\title{
KAJIAN LAPANG BUDIDAYA KERAMBA JARING APUNG IKAN NILA “MANDIRI” DI WADUK CIRATA DAN JATILUHUR
}

\author{
Estu Nugroho \\ Balai Riset Perikanan Budidaya Air Tawar \\ Jl. Sempur No. 1, Bogor 16154 \\ E-mail:engroho@yahoo.com
}

\begin{abstract}
ABSTRAK
Budidaya ikan nila berkembang sebagai agribisnis yang menguntungkan. Sentra budidaya ikan nila di Jawa Barat terdapat di Waduk Jatiluhur dan Cirata. Umumnya budidaya ikan nila dilakukan melalui sistem "kolor" yaitu memelihara ikan nila di bagian bawah KJA sedangkan di atas dipelihara ikan mas (ikan nila tidak diberi pakan langsung). Pada sistem ini ketergantungan budidaya ikan nila terhadap ikan mas sangat besar. Dewasa ini pemeliharaan ikan mas di keramba jaring apung (KJA) semakin berkurang sebagai akibat dari wabah penyakit oleh koi herpesvirus (KHV), keadaan ini juga turut mempengaruhi budidaya ikan nila di bawahnya, di mana petani tidak lagi memelihara ikan nila sebagai ikan "ikutan". Kajian lapang yang melihat kemungkinan ikan nila dipelihara secara "mandiri" di KJA telah dicoba di Waduk Jatiluhur dan Cirata. Kesinambungan bisnis ikan nila di Waduk Jatiluhur dan Cirata dapat dilakukan dengan menggunakan sistem pemeliharaan model mandiri dengan kepadatan 30 ekor $/ \mathrm{m}^{2}$ dengan jaminan harga jual ikan nila di atas $\operatorname{Rp} 11.000,-/ \mathrm{kg}$.
\end{abstract}

KATA KUNCI: $\quad$ keramba jaring apung (KJA), nila mandiri

\section{PENDAHULUAN}

Ikan nila (Oreochromis niloticus) atau juga disebut ikan tilapia merupakan salah satu jenis ikan air tawar introduksi yang mempunyai nilai ekonomis yang cukup penting di beberapa daerah di Asia, termasuk Indonesia.

Ikan nila didatangkan pertama kali ke Indonesia pada tahun 1969 dan sejak itu budidayanya perkembang dengan sangat cepat. Hal ini disebabkan ikan nila mempunyai kemampuan adaptasi yang relatif baik terhadap lingkungan serta mudah dipijahkan sehingga mendukung pengembangan budidaya di masyarakat.
Perkembangan perikanan budidaya air tawar dalam hal ini ikan nila sebagai salah satu kegiatan agribisnis mulai disadari dan digarap dengan baik terjadi pada tahun 1990an. Salah satu sentra kegiatan agribisnis ikan nila adalah Daerah Jawa Barat. Dimulainya kegiatan ini ada kaitannya dengan mulai berfungsinya beberapa waduk buatan di daerah Jawa Barat antara lain: Waduk Saguling, Cirata, dan Ir. H. Juanda di Jatiluhur.

Dewasa ini tercatat hampir sekitar 8.000 ton pakan dibutuhkan untuk budidaya ikan di Waduk Cirata. Jika produksi ikan nila adalah sepertiga dari produksi ikan mas maka produk ikan nila yang dikeluarkan dari KJA Cirata mencapai sekitar 1.500 ton untuk setiap bulannya, dan jika dinilai dalam rupiah merupakan jumlah yang cukup besar ( Rp 14,2 M; dengan harga ikan nila saat ini Rp $9.500,-/ \mathrm{kg}$ ) belum termasuk nilai hasil perbenihannya.

Kenyataan ini semakin memperkuat keyakinan kita bahwa agribisnis ikan nila merupakan suatu kegiatan yang menjanjikan keuntungan. Namun demikian, penanganan yang profesional dalam menjalankan sistem bisnis ini juga diperlukan untuk menjamin kelangsungan hidup atau kelanggengan usaha agribisnis ikan air tawar ini.

\section{SISTEM BUDIDAYA “KOLOR” DI CIRATA DAN JATILUHUR}

Budidaya ikan nila pada umumnya dilakukan bersamaan dengan budidaya ikan mas. Para pembudidaya memelihara ikan nila di bawah jaring yang digunakan untuk memelihara ikan mas. Sistem ini dikenal dengan sebutan sistem "kolor". Sistem kolor ditemukan secara tidak sengaja oleh pembudidaya di Waduk Cirata dengan tujuan utuk memanfaatkan pakan yang tidak dimakan oleh ikan mas. Namun demikian budidaya nila dengan sistem ini sangat tergantung oleh keadaan budidaya ikan mas sendiri. Penemuan ini segera berkembang dengan pesatnya, karena para pembudidaya mendapatkan keuntungan ganda, satu berasal dari budidaya ikan mas dan lainnya dari ikan nila. Bahkan dalam perkembangan selanjutnya, budidaya ikan nila menjadi tulang punggung para pembudidaya, mengingat budidaya ikan mas mengalami kendala yang tidak kecil di antaranya ialah serangan oleh virus herpes 
koi (KHV) sehingga mengurangi keuntungan yang diperoleh bahkan beberapa di antaranya mengalami kerugian.

Kerugian demi kerugian yang dialami pada budidaya ikan mas membuat para pembudidaya memberhentikan usaha budidaya ikan mas, sehingga ikan nila yang dipelihara bersama ikan mas pun juga mengalami nasib yang serupa. Salah satu solusinya adalah memelihara ikan nila secara mandiri, yaitu di kantong jaring yang paling atas tempat pemeliharaan ikan mas. Kajian yang komprehensif dalam pengembangan budidaya ikan nila secara mandiri sangat ditunggu oleh para pembudidaya di Waduk Cirata dan Jatiluhur dalam membantu kesinambungan bisnis perikanannya, di samping alternatif beralih pada komoditas yang lebih tahan terhadap kendala serangan virus seperti bawal dan gurame.

\section{KEPADATAN YANG OPTIMAL}

Salah satu faktor penting yang mempengaruhi keberhasilan suatu usaha dalam budidaya ikan air tawar di antaranya adalah kepadatan ikan per satuan luas yang digunakan. Pemilihan tingkat kepadatan yang tepat akan berpengaruh terhadap efisiensi penggunaan pakan, jenis teknologi, serta skala usaha yang dijalankan yang pada akhirnya kesemuanya akan bermuara pada tingkat Harga Pokok Produksi (HPP) yaitu suatu nilai besaran biaya yang diperlukan untuk memproduksi per satuan bobot suatu produk perikanan.

Tingkat HPP yang dapat ditekan serendah-rendahnya akan membuat produk yang dihasilkan dapat bersaing di pasaran dengan variasi harga jual yang sangat besar karena adanya kelebihan marjin yang bisa dimanfaatkan untuk kelanggengan usaha budidaya ikan.

Empat tingkat padat tebar ikan nila yang berukuran 8-12 g telah dicoba dalam pemeliharaan ikan nila secara mandiri di KJA Waduk Jatiluhur dan Cirata selama 70 hari (sampai mencapai ukuran pasar saat ini). Adapun tingkat kepadatannya adalah: 10, 20, 30, dan 40 ekor per $\mathrm{m}^{2}$. Ikan nila diberi pakan berupa pelet komersial tenggelam dengan ransum sebanyak 4\%-5\% bobot biomassa ikan, dengan frekuensi pemberian sebanyak $3 \times$ sehari. Sampling dilakukan setiap 2 minggu dengan parameter sintasan, pertambahan bobot, konversi pakan, serta produksi yang dicapai.

\section{Sintasan Ikan (Effendie, 1979)}

Secara umum, pemeliharaan ikan nila secara mandiri dengan berbagai tingkat kepadatan mempunyai sintasan rata-rata $86,77 \%$ di Waduk Jatiluhur dan $80,48 \%$ di Waduk Cirata. Selama pemeliharan 70 hari tercatat bahwa sintasan yang paling kecil nilainya adalah $77,90 \%$ yang diamati pada kepadatan 40 ekor per $\mathrm{m}^{2}$ di Waduk Cirata, sedangkan nilai yang terbesar adalah $89,95 \%$ yang diamati pada kepadatan 20 ekor per $\mathrm{m}^{2}$ di Waduk Jatiluhur (Tabel 1).

Tabel 1. Sintasan ikan nila yang dipelihara di KJA dengan tingkat kepadatan yang berbeda

\begin{tabular}{|c|c|c|c|c|c|}
\hline \multirow{2}{*}{ Lokasi } & \multicolumn{4}{|c|}{ Kepadatan } & \multirow[t]{2}{*}{ Rataan } \\
\hline & 10 & 20 & 30 & 40 & \\
\hline \multirow[t]{3}{*}{ Jatiluhur } & 74,75 & 89,85 & 84,50 & 91,84 & \\
\hline & 82,01 & 89,51 & 90,64 & 87,94 & \\
\hline & 80,78 & 90,51 & 91,69 & 87,20 & \\
\hline Rataan & 79,18 & 89,95 & 88,94 & 88,99 & 86,77 \\
\hline \multirow[t]{2}{*}{ Cirata } & 72,65 & 86,76 & 81,60 & 77,90 & \\
\hline & 84,95 & 79,89 & 82,17 & 77,90 & \\
\hline Rataan & 78,80 & 83,32 & 81,88 & 77,90 & 80,48 \\
\hline
\end{tabular}

Nilai sintasan ikan nila yang dipelihara di Waduk Jatiluhur secara keseluruhan lebih baik dibandingkan nilai sintasan ikan nila yang dipelihara di Waduk Cirata. Tingkat kepadatan $20 \mathrm{ekor} / \mathrm{m}^{2}$ mempunyai nilai sintasan yang terbaik pada pemeliharaan ikan nila di kedua waduk tersebut, yaitu 89,95\% (Jatiluhur) dan 83.32\% (Cirata). Secara statistik, tingkat kepadatan memberikan pengaruh yang berbeda nyata pada sintasan ikan nila di kedua waduk. Di Waduk Jatiluhur, kepadatan 10 ekor $/ \mathrm{m}^{2}$ memberikan pengaruh yang berbeda nyata terhadap sintasan dengan kepadatan 20, 30, 40 ekor $/ \mathrm{m}^{2}$, dan di antara ketiganya tidak berbeda nyata. Sedangkan di Waduk Cirata, kepadatan $40 \mathrm{ekor} / \mathrm{m}^{2}$ berbeda nyata dengan kepadatan 10,20, $30 \mathrm{ekor} / \mathrm{m}^{2}$ pada sintasan benih, dan di antara ketiganya tidak berbeda nyata.

Fenomena ini menunjukkan bahwa kepadatan 20 ekor/ $\mathrm{m}^{2}$ memberikan pengaruh yang terbaik pada sintasan benih ikan nila yang dipelihara di KJA Jatiluhur dan Cirata. Lebih baiknya sintasan di Waduk Jatiluhur dibandingkan Waduk Cirata mungkin dipengaruhi oleh kualitas air yang ada di kedua waduk tersebut.

\section{Pertambahan Bobot}

Tingkat kepadatan ikan nila memberikan pengaruh yang bervariasi terhadap pertambahan bobot ikan nila selama pemeliharaan 70 hari. Rata-rata pertambahan bobot relatif harian berkisar antara $11,21 \%$ di Waduk Cirata dan 12,96\% di Waduk Jatiluhur (Tabel 2).

Pertambahan bobot relatif terkecil didapatkan pada tingkat kepadatan 40 ekor $/ \mathrm{m}^{2}$ di Waduk Cirata $(8,78 \%)$, 
Tabel 2. Pertambahan bobot relatif harian (\%)

\begin{tabular}{lccccc}
\hline \multirow{2}{*}{ Lokasi } & \multicolumn{5}{c}{ Kepadatan } \\
\cline { 2 - 5 } & $\mathbf{1 0}$ & $\mathbf{2 0}$ & $\mathbf{3 0}$ & $\mathbf{4 0}$ & \\
\hline Jatiluhur & 23,87 & 20,20 & 17,51 & 9,09 & \\
& 11,43 & 12,60 & 10,15 & 8,22 & \\
& 13,06 & 10,15 & 9,09 & 10,22 & \\
\hline Rataan & $\mathbf{1 6 , 1 2}$ & $\mathbf{1 4 , 3 2}$ & $\mathbf{1 2 , 2 5}$ & $\mathbf{9 , 1 8}$ & $\mathbf{1 2 , 9 6}$ \\
\hline Cirata & 10,63 & 14,08 & 9,43 & 6,92 & \\
& 16,70 & 10,62 & 10,64 & 10,63 & \\
\hline \multirow{2}{*}{ Rataan } & $\mathbf{1 3 , 6 6}$ & $\mathbf{1 2 , 3 5}$ & $\mathbf{1 0 , 0 4}$ & $\mathbf{8 , 7 8}$ & $\mathbf{1 1 , 2 1}$ \\
\hline
\end{tabular}

sedangkan pertambahan bobot relatif terbesar diamati pada kepadatan ikan nila $10 \mathrm{ekor} / \mathrm{m}^{2}$ di Waduk Jatiluhur $(16,12 \%)$. Nilai pertambahan bobot relatif harian ikan nila yang dipelihara di Waduk Jatiluhur lebih baik dibandingkan nilai pertambahan bobot relatif harian ikan nila yang dipelihara di Waduk Cirata pada setiap tingkat padat tebar.

Tingkat kepadatan 10 ekor $/ \mathrm{m}^{2}$ di Waduk Jatiluhur dan Cirata mempunyai pertambahan bobot relatif harian yang tertinggi. Secara statistik, terdapat perbedaan yang nyata pada pertambahan bobot relatif harian akibat tingkat kepadatan yang digunakan. Tingkat kepadatan 10, 20, 30 ekor/ $\mathrm{m}^{2}$ berbeda nyata dengan tingkat kepadatan 40 ekor/ $\mathrm{m}^{2}$, dan tidak berbeda nyata di antara ketiga tingkat kepadatan (Jatiluhur). Demikian pula halnya terjadi di Waduk Cirata, tingkat kepadatan $10 \mathrm{ekor} / \mathrm{m}^{2}$ mempunyai pengaruh yang berbeda nyata pada pertambahan bobot relatif harian ikan nila dibandingkan dengan kepadatan $40 \mathrm{ekor} / \mathrm{m}^{2}$, dan tidak berbeda nyata di antara 10, 20, 30 ekor $/ \mathrm{m}^{2}$ serta antara 20,30 , dan $40 \mathrm{ekor} / \mathrm{m}^{2}$.

Fenomena ini menunjukkan bahwa kepadatan 10, 20, $30 \mathrm{ekor} / \mathrm{m}^{2}$ memberikan pengaruh yang terbaik pada pertumbuhan benih ikan nila yang dipelihara di KJA Jatiluhur dan Cirata. Sintasan di Waduk Jatiluhur lebih baik dibandingkan Waduk Cirata mungkin dipengaruhi oleh kualitas air yang ada di kedua waduk tersebut.

\section{Rasio Konversi Pakan (Food Conversion Ratio)}

Rasio konversi pakan menunjukkan jumlah pakan yang diubah menjadi daging ikan (National Research Council, 1977). Secara umum, rata-rata rasio konversi pakan adalah 1,04 di Waduk Cirata dan 1,11 di Waduk Jatiluhur (Tabel 3).

Rasio konversi pakan terkecil didapatkan pada kepadatan 30 ekor $/ \mathrm{m}^{2}$ di Waduk Cirata $(0,95)$ dan yang terbesar di kepadatan $10 \mathrm{ekor} / \mathrm{m}^{2}$ di Waduk Jatiluhur $(1,26)$.
Tabel 3. Rasio konversi pakan

\begin{tabular}{lccccc}
\hline \multirow{2}{*}{ Lokasi } & \multicolumn{5}{c}{ Kepadatan } \\
\cline { 2 - 5 } & $\mathbf{1 0}$ & $\mathbf{2 0}$ & $\mathbf{3 0}$ & $\mathbf{4 0}$ & \\
\hline \multirow{2}{*}{ Jatiluhur } & 0,89 & 0,82 & 0,81 & 1,06 & \\
& 1,34 & 1,05 & 1,05 & 1,12 & \\
& 1,56 & 1,19 & 1,12 & 1,25 & \\
\hline Rataan & $\mathbf{1 , 2 6}$ & $\mathbf{1 , 0 2}$ & $\mathbf{1 , 0 0}$ & $\mathbf{1 , 1 5}$ & $\mathbf{1 , 1 1}$ \\
\hline Cirata & 1,11 & 0,92 & 0,97 & 1,23 & \\
& 0,82 & 1,31 & 0,93 & 1,01 & \\
\hline Rataan & $\mathbf{0 , 9 7}$ & $\mathbf{1 , 1 2}$ & $\mathbf{0 , 9 5}$ & $\mathbf{1 , 1 2}$ & $\mathbf{1 , 0 4}$ \\
\hline
\end{tabular}

Nilai konversi pakan ikan nila di Waduk Cirata lebih baik dibandingkan ikan nila di Waduk Jatiluhur pada setiap tingkat kepadatan.

Tingkat kepadatan 30 ekor $/ \mathrm{m}^{2}$ di Waduk Jatiluhur dan Cirata mempunyai tingkat rasio konversi pakan yang terendah. Secara statistik tidak terdapat perbedaan yang nyata antara tingkat kepadatan. Lebih rendahnya rasio konversi pakan di Waduk Cirata dimungkinkan akibat tingkat kesuburan yang lebih tinggi dibandingkan tingkat kesuburan di Jatiluhur. Satu hal yang masih perlu dikaji lebih jauh adalah tingkat kepadatan rendah $\left(10 \mathrm{ekor} / \mathrm{m}^{2}\right)$ mempunyai nilai FCR yang tertinggi sedangkan di Cirata tertinggi rata-rata nilai FCR teramati pada kepadatan 20 dan 40 ekor $/ \mathrm{m}^{2}$.

\section{PRODUKSI DAN HARGA POKOK}

Hal penting yang menjadi dorongan para pembudidaya untuk melanjutkan kiprahnya dalam bisnis adalah tingkat produksi dan harga pokok produksi (HPP). Keduanya sangat mempengaruhi keputusan-keputusan yang akan diambil oleh pembudidaya dalam menjalankan usahanya.

Pembudidaya akan mencari alternatif teknologi ataupun jenis sistem budidaya ikan dalam rangka mendapatkan HPP ikan yang diproduksinya serendah mungkin sehingga masih tersisa marjin keuntungan yang cukup besar dalam suatu bisnis budidaya ikan. Jika marjinnya hanya sedikit maka alternatif lainnya adalah mendongkrak tingkat budidayanya setinggi mungkin sehingga total marjinnya pun akan meningkat.

Tidak setiap tingkat produksi yang tinggi lebih baik daripada tingkat produksi yang lebih rendah, demikian pula tidak menutup kemungkinan teknologi yang sederhana mempunyai keuntungan yang lebih baik daripada tingkat teknologi yang lebih tinggi. Kesemuanya akan tergantung pada ketelitian dan ketekunan 
pembudidaya dalam menjalankan operasional budidaya ikan yang sedang digelutinya.

Secara umum tingkat produksi ikan nila di KJA Waduk Jatiluhur lebih tinggi dibandingkan yang dilakukan di Waduk Cirata, yaitu sekitar 3,96\% (Tabel 4). Pada semua tingkat kepadatan, kecuali kepadatan $10 \mathrm{ekor} / \mathrm{m}^{2}$, maka produksi budidaya ikan nila di Waduk Jatiluhur lebih baik dibandingkan budidaya ikan nila yang ada di Waduk Cirata. Perbedaan tertinggi tercatat pada produksi ikan nila dengan kepadatan 30 ekor $/ \mathrm{m}^{2}$ yaitu sebanyak 6,65\%. Sedangkan pada kepadatan $10 \mathrm{ekor} / \mathrm{m}^{2}$. Budidaya ikan nila di Waduk Cirata lebih baik sebesar 5,7\% dibandingkan budidaya ikan nila di Waduk Jatiluhur.

Tabel 4. Produksi ikan selama pemeliharaan 70 hari $(\mathrm{kg})$

\begin{tabular}{lccccc}
\hline \multirow{2}{*}{ Lokasi } & \multicolumn{5}{c}{ Kepadatan } \\
\cline { 2 - 5 } & $\mathbf{1 0}$ & $\mathbf{2 0}$ & $\mathbf{3 0}$ & 40 & \\
\hline \multirow{2}{*}{ Jatiluhur } & 225,00 & 449,00 & 549,00 & 575,00 & \\
& 155,00 & 381,00 & 470,00 & 505,00 & \\
& 172,00 & 308,00 & 432,00 & 462,00 & \\
\hline Rataan & $\mathbf{1 8 4 , 0 0}$ & 379,33 & 483,67 & 514,00 & 390,25 \\
\hline Cirata & 141,00 & 429,00 & 428,00 & 419,00 & \\
& 248,00 & 310,00 & 479,00 & 549,00 & \\
\hline Rataan & $\mathbf{1 9 4 , 5 0}$ & $\mathbf{3 6 9 , 5 0}$ & 453,50 & 484,00 & 375,38 \\
\hline
\end{tabular}

Keterangan:

HPP terdiri atas: benih, pakan, tenaga kerja, dan penyusutan KJA

Pada Tabel 4 tertera bahwa, HPP terkecil pada produksi ikan nila di Waduk Jatiluhur dengan kepadatan 30 ekor $/ \mathrm{m}^{2}$ yaitu $\mathrm{Rp} 7.999,-/ \mathrm{kg}$, demikian pula kepadatan $30 \mathrm{ekor} / \mathrm{m}^{2}$ budidaya ikan nila di Waduk Cirata mempunyai HPP yang terendah (Rp 8.236,-/kg). Pada umumnya HPP budidaya ikan nila di Waduk Jatiluhur lebih rendah dibandingkan HPP budidaya ikan nila di Waduk Cirata $(0,4 \%)$.

Diketahui bahwa dengan menaikkan kepadatan sebesar $10 \mathrm{ekor} / \mathrm{m}^{2}$ pada awalnya dapat menurunkan HPP budidaya ikan nila di kedua waduk. Namun setelah kepadatan 30 ekor $/ \mathrm{m}^{2}$, ternyata kenaikkan kepadatan justru menaikkan pula HPP budidaya ikan nila di kedua waduk. Hal ini mengindikasikan bahwa kepadatan yang dapat menaikkan marjin keuntungan adalah di bawah 30 ekor $/ \mathrm{m}^{2}$, namun demikian perlu diteliti lebih komprehensif dengan membandingkan harga jual pada saat ini sehingga besarnya keuntungan dapat di estimasi dan diprediksi satuan kepadatan mana yang memberikan marjin terbanyak.
Tabel 5. Harga pokok produksi per kilogram ikan nila

\begin{tabular}{lccccc}
\hline \multirow{2}{*}{ Lokasi } & \multicolumn{5}{c}{ Kepadatan } \\
\cline { 2 - 5 } & $\mathbf{1 0}$ & $\mathbf{2 0}$ & $\mathbf{3 0}$ & $\mathbf{4 0}$ & \\
\hline Jatiluhur & 8.036 & 6.425 & 6.584 & 8.475 & \\
& 12.129 & 8.343 & 8.445 & 9.129 & \\
& 13.071 & 9.637 & 8.968 & 9.700 & \\
\hline Rataan & $\mathbf{1 1 . 0 7 8}$ & $\mathbf{8 . 1 3 5}$ & $\mathbf{7 . 9 9 9}$ & $\mathbf{9 . 1 0 1}$ & $\mathbf{9 . 0 7 8}$ \\
\hline Cirata & 11.518 & 7.491 & 8.470 & 10.657 & \\
& 7.588 & 10.452 & 8.002 & 8.761 & \\
\hline Rataan & $\mathbf{9 . 5 5 3}$ & $\mathbf{8 . 9 7 1}$ & $\mathbf{8 . 2 3 6}$ & $\mathbf{9 . 7 0 6}$ & $\mathbf{9 . 1 1 7}$ \\
\hline
\end{tabular}

\section{MASA DEPAN KESINAMBUNGAN BISNIS NILA DI JATILUHUR DAN CIRATA}

Seperti telah disinggung di depan, kebersinambungan bisnis budidaya ikan nila di Waduk Jatiluhur dan Cirata telah dalam persimpangan jalan dengan mulai memudarnya kegiatan bisnis budidaya ikan mas di kedua waduk tersebut yang diakibatkan adanya sistem kolor.

Hasil kajian tentang budidaya ikan nila secara mandiri dengan berbagai tingkat kepadatan telah dilakukan dengan menunjukkan hasil yang cukup memuaskan. Di mana ikan nila dapat memanfaatkan pakan komersial dengan baik yang ditunjukkan dengan nilai rasio konversi pakan yang cukup baik yaitu 1,04 (Cirata) dan 1,11 (Jatiluhur).

Namun demikian kesinambungan budidaya ikan nila secara mandiri ini sangat bergantung pada harga jual ikan nila yang terjadi di kedua waduk tersebut. Jika harga ikan nila di tingkat pembudidaya di kedua waduk di atas $\mathrm{Rp}$ $9.500,-/ \mathrm{kg}$ maka masih memungkinkan pembudidaya untuk dapat menikmati marjin keuntungan yang ada. Namun sebaliknya jika harga ikan nila jatuh di bawah Rp 9.000,-/kg maka kemungkinan model ini untuk dikembangkan di masyarakat pada kedua waduk sangat kecil.

Pada saat ini (Februari 2011), harga ikan nila per kilogramnya sangat baik yaitu mencapai Rp 12.500,-. Kenaikan ini disebabkan oleh menurunnya pasokan ikan tangkapan dari laut sebagai efek dari cuaca yang tidak bersahabat. Naiknya harga konsumsi ikan ternyata juga mulai diikuti oleh kenaikkan harga benih dan pakan, di mana kenaikkannya sebesar 10\%-15\%. Dengan demikian maka diperkirakan HPP budidaya ikan nila di kedua waduk juga bertambah sebesar 10\%-15\% sehingga HPP untuk saat ini adalah sekitar Rp 10.000,-/kg.

Sebagai contoh pola kepadatan yang sesuai untuk budidaya ikan di kedua waduk (dengan mengesampingkan 
kenaikkan harga benih dan pakan), maka dapat dijelaskan sebagai berikut: jika harga jual ikan nila per kilogram besarnya adalah $\mathrm{Rp} 12.500$,- maka marjin yang dapat dinikmati oleh para pembudidaya di Jatiluhur per petaknya pada tingkat kepadatan 10 ekor/ $\mathrm{m}^{2}$ adalah Rp 261.648,-; Rp 1.655.775,- (20 ekor/m²); Rp 2.176.998,- (30 ekor $\left./ \mathrm{m}^{2}\right)$; dan Rp 1.747.086,- $\left(40 \mathrm{ekor} / \mathrm{m}^{2}\right)$. Sedangkan pembudidaya ikan nila di Waduk Cirata diperkirakan akan mendapat marjin sebesar Rp 573.191,- (10 ekor/m²); Rp 1.303.965,$\left(20\right.$ ekor $\left./ \mathrm{m}^{2}\right)$; Rp 1.933.724,- $\left(30\right.$ ekor $\left./ \mathrm{m}^{2}\right)$; dan $\mathrm{Rp}$ $1.350 .844,-\left(40 \mathrm{ekor} / \mathrm{m}^{2}\right)$.

Dari perhitungan tersebut terlihat bahwa marjin terbesar adalah pada pemeliharaan ikan nila secara mandiri selama 70 hari dengan kepadatan 30 ekor $/ \mathrm{m}^{2}$ di Waduk Jatiluhur dan Waduk Cirata. Dengan perbedaan marjin di antara keduanya mencapai Rp 243.274,-. Melihat cukup besarnya nilai marjin yang didapat per petaknya di kedua waduk tersebut maka diperkirakan budidaya ikan nila secara mandiri dapat menjadi alternatif kebersinambungan bisnis perikanan di Waduk Jatiluhur dan Cirata dengan syarat harga jual dapat dijaga seperti saat ini yaitu dikisaran (Rp 11.000,-- Rp 13.000,-/kg). Dan ini menjadi pekerjaan rumah dari instansi terkait dalam hal ini
Kementerian Kelautan dan Perikanan (KKP) untuk turut berkiprah menjamin kelanggengan usaha budidaya ikan, khususnya ikan nila, dari pengaruh para spekulan yang ditenggarai mempunyai pengaruh signifikan dalam menetapkan harga jual produk perikanan (ikan segar). Hal lainnya adalah mencari suatu terobosan agar ikan nila tidak hanya dijual dalam bentuk segar namun juga dalam bentuk olahan sehingga makin menambah marjin dan kesejahteraan para pembudidaya ikan di kedua waduk khususnya, dan di Indonesia secara umum.

\section{PENUTUP}

Kesinambungan bisnis ikan nila di Waduk Jatiluhur dan Cirata dapat dilakukan dengan menggunakan sistem pemeliharaan model mandiri dengan kepadatan 30 ekor $/ \mathrm{m}^{2}$ dengan jaminan harga jual ikan nila di atas $\mathrm{Rp}$ $11.000,-/ \mathrm{kg}$.

\section{DAFTAR ACUAN}

Effendie, M.I. 1979. Metode biologi perikanan. Yayasan Dewi Sri, Bogor.

National Research Council. 1977. Nutrient Requirement of warmwater Fishes. National Academy of Sciences. Washington D.C., 71 pp. 